\title{
Heathland Restoration Techniques: Ecological Consequences for Plant-Soil and Plant-Animal Interactions
}

\author{
Anita Diaz, Iain Green, and Damian Evans \\ School of Applied Sciences, Bournemouth University, Talbot Campus, Fern-Barrow, Poole, Dorset BH12 5BB, UK \\ Correspondence should be addressed to Anita Diaz, adiaz@bournemouth.ac.uk \\ Received 9 August 2011; Accepted 15 September 2011 \\ Academic Editors: C. Geron and C. F. J. Meyer \\ Copyright () 2011 Anita Diaz et al. This is an open access article distributed under the Creative Commons Attribution License, \\ which permits unrestricted use, distribution, and reproduction in any medium, provided the original work is properly cited.
}

\begin{abstract}
We compare the soil and plant community development during heathland restoration on improved farmland when achieved through soil stripping with that achieved through soil acidification. We also test the potential for toxic metals to be made more available to plant and animal species as a result of these treatments. Acidification with elemental sulphur was found to be more effective than soil stripping for establishing an ericaceous sward despite the high levels of phosphate still present within the soil. However, both soil acidification and soil stripping were found to have the potential to increase the availability of potentially toxic metals. Acidification increased uptake of both aluminium and zinc in two common plant species Agrostis capillaris and Rumex acetosella and decreased the abundance of surface active spiders. The potential consequences for composition of restored heathland communities and for functioning of food chains are discussed.
\end{abstract}

\section{Introduction}

The restoration of lowland heath is an important facet of heathland conservation, as restored heathlands can ameliorate the effect of habitat fragmentation and so reduce the risk of extinction debt [1]. Much heathland has been destroyed through agricultural intensification during the second half of the last century $[2,3]$. Consequently, there has been considerable long-standing interest in methods for the restoration of heathland on improved agricultural land [4-14]. Such restoration requires a reversal of the increased soil $\mathrm{pH}$ and nutrient availability that is effected during agricultural improvement so that ericaceous and acid grassland species are not outcompeted by large-growing mesotrophic grasses. Successful approaches have been based on either physically removing the improved topsoil $[15,16]$ or chemically amending it by, for example, adding sulphur to reduce $\mathrm{pH}$ and macronutrient concentrations $[17,18]$.

Whilst it is encouraging that some heathland restoration attempts based on either soil removal or soil acidification are successfully establishing ericaceous covers, the evaluation of successful habitat restoration should encompass a far broader assessment of the extent to which the communities and ecological processes of the restored ecosystems show similarity with those of target, established ecosystems [19].
This is particularly true for heathland restoration, as an important aim is often to provide habitat for higher trophic level protected species such as stone curlew (Burhinus oedicnemus), nightjar (Caprimulgus europaeus), and sand lizard (Lacerta agilis) that can have significant parts of their life cycles associated with heathlands. Key factors for all these species are appropriate vegetation structure and composition and the availability of surface dwelling invertebrate prey. For example, stone curlew nest on open land including grass heaths and chicks usually forage within $100 \mathrm{~m}$ of their nest for surface-active invertebrates such as beetles, woodlice, molluscs, and worms $[20,21]$. Beetles have been shown to constitute approximately a third of the diet of stonechat chicks with ground beetles alone accounting for a fifth of the total diet; hymenoptera and spiders were also found to be important elements [22]. The availability of invertebrate prey has also been suggested as a possible factor affecting the recolonisation of sites by nightjar [23].

The ecosystem function of newly restored heaths may also differ from that of long-established heaths if the heathland restoration process changes available metal concentrations in soils and these metals are transferred up through tropic levels. Soil acidification, especially below $\mathrm{pH} 5-5.5$, can markedly increase the solubility of potentially toxic metal ions and so increase their mobility into biological systems 
$[24,25]$. Potentially toxic metals (PTMs) can, in extreme cases, cause lethal effects to invertebrates in higher trophic levels $[26,27]$. However, even relatively low levels of exposure can produce behavioral and sublethal effects that reduce fitness and potentially population size [28]. Some edaphic invertebrates can accumulate very high levels of trace metals in their bodies when subject to trace metal contamination $[29,30]$ increasing exposure of their predators to these metals. It is known that this process of metal accumulation can be enhanced by a decrease in the $\mathrm{pH}$ of sandy soil [31]. However, the extent to which potentially toxic metals are mobilised in the soil and transferred through food chains in restored heaths is currently unknown. Potentially toxic metals can reduce the diversity and abundance of both carabid beetles and spiders $[32,33]$. Thus, changes in these two predator guilds may indicate damaging effects stemming from metal mobilization as well as having implications for higher trophic levels feeding on them.

Existing research on restoration of lowland heath has reported the effect of heathland restoration techniques on soil chemistry and plant communities, but has not yet examined the effect on animal communities nor explored any aspect of ecosystem function of restored heaths. In this paper we present a first attempt to explore these issues by combining the results of three field investigation into heathland restoration by soil stripping and soil acidification. There were three specific objectives: (1) to compare the two methods in terms of how successful they are at producing soil chemical conditions and plant communities that resemble those of adjacent target seminatural heathlands, (2) to test whether PTMs are mobilised and enter food chains via plant uptake as a result of heathland restoration methods and (3) to investigate effects on beetle and spider abundance that may reflect the mobilisation of PTMs.

\section{Methods}

2.1. Study Areas and Experimental Designs. The first two objectives are examined at the "Dorset" study area which is located near to Corfe Castle, Dorset, England, UK (Latitude: 50.63 Longitude: -2.05 ) on two contiguous farms (Newlines Farm and Hartland Farm) owned by the National Trust and on adjacent long-established heathland. Until the mid 20th century, the farms were unimproved lowland heathland (Langton Wallis Heath and New Mills Heath) established on a mix of acidic fluvially deposited sands, gravels, and clays of bagshot beds. Agricultural improvement in the latter half of the 20th century involved the addition of rock phosphate (apatite bearing rock $\mathrm{Ca}_{10}\left(\mathrm{PO}_{4}\right) 6 \mathrm{~F}_{2}$ ) and chalk and marl (amorphous $\mathrm{CaCO}_{3}: \mathrm{MgCO}_{3}$ at a ratio of approximately $30: 1$ ) to increase nutrient levels and decrease soil acidity. These treatments raise $\mathrm{pH}$ and phosphate levels for many decades. For objective 1, we established a factorial experiment to compare the efficacy for heathland restoration of soil stripping versus soil acidification. In each of five fields on each farm, we set up a $50 \mathrm{~m} \times 50 \mathrm{~m}$ sulphur treatment plot, a soil stripped treatment plot, and a control. Fields were chosen to be as homogeneous as possible, and treatment plots were arranged at random on each field. We also sampled 10 areas of heath lying immediately adjacent to the fields to provide a target in terms of soil chemical status and plant and animal community restoration. The elemental sulphur treatment used pellets of Brimestone 90 and was applied as one plot per field in two stages; $2000 \mathrm{~kg} \mathrm{ha}^{-1}$ was applied in May 2000 and a further $1600 \mathrm{~kg} \mathrm{ha}^{-1}$ at the end of March 2001. This resulted in a total dose of $3600 \mathrm{~kg} \mathrm{ha}^{-1}$ which lies within the range reported as successful in supporting the growth of acid grassland and ericaceous species by previous research [11]. The elemental sulphur is converted to sulphuric acid over a period of months by microbial oxidation. The soil stripping treatment plots were set up in March 2001 and soil was stripped down to a depth of $20 \mathrm{~cm}$. Clippings of Calluna vulgaris (L.) Hull. bearing seed were sown on all 30 farmland plots in November 2001, and spread at a rate of twice the area from which the clippings had been obtained [34].

For objective 2, we investigated the effect of different application rates of elemental sulphur on potentially toxic metal uptake by plants by examining uptake by two key plant species: Agrostis capillaris L. and Rumex acetosella L. These species were chosen because they are abundant on lowland acid grassland and heaths and are two of the first species to colonise heathland restoration sites. Fifteen plots measuring $4 \mathrm{~m} \times 4 \mathrm{~m}$ were set up in a fully randomised design on improved pasture at the Hartland site. The treatment applications rates were, $0,900,1800,2400$, and $3600 \mathrm{~kg} \mathrm{ha}^{-1}$. There were three replicates per treatment. In each plot, ten random shoots were collected of each species. These were collected two years after treatment application during initial sward establishment. The third objective was examined at another study area "Pembrokeshire" which is located on Trehill farm near Marloes, Pembrokeshire, Wales, UK (Latitude: 51.73167, Longitude: -5.19333$)$. The reason for this was that this site afforded a range of different sulphur application rates at a patch scale that was larger than typical home ranges for beetles and spiders. Consequently we were able to assess the effects of soil acidification on the invertebrates living under a wide range of specific level of soil acidification. Trehill Farm is owned by the National Trust and was heathland that was lost to improvement for arable production in the 20th century. In 2004, ground-up lumps of elemental sulphur originating from Chevron-Texaco's Pembroke refinery sulphur emissions recovery system were applied across approximately 200 ha. The nature of the variable sized pieces of sulphur and of the spreading process, using a conventional lime spreader, resulted in uneven application rates which we were able to make use of for addressing objective 3 .

2.2. Soil Chemistry Sampling and Analysis. Bulk soil samples comprising 25 random subsamples were taken from the top $10 \mathrm{~cm}$ of the $A_{P}$ horizon of each of the 30 plots of the "Dorset" study site and 100 subsamples in the "Pembrokeshire" study site in June 2006. Soil samples were air-dried and ground gently before being passed through a $2 \mathrm{~mm}$ plastic sieve. Subsequent soil analysis was carried out in duplicate on this fraction. Soil $\mathrm{pH}$ was determined in a $2.5: 1$ water soil suspension. Extractable (i.e., in the soil solution or bound to 
TABLE 1: Chemical soil attributes across each treatment, control, and target heathland. Concentrations are in $\mathrm{mgL}^{-1}$. $\mathrm{H}=\mathrm{Kruskal}-\mathrm{Wallis}$ test statistic.

\begin{tabular}{lcccccc}
\hline \multirow{2}{*}{ Soil attribute } & \multicolumn{7}{c}{ Treatment } & \multirow{2}{*}{ H } & \multirow{2}{*}{$P$} \\
\hline $\mathrm{pH}$ & Control & Elemental sulphur & Soil stripped & Heathland & & $<0.001$ \\
Phosphate & 5.7 & 4.7 & 6.3 & 4.1 & 30.22 & 0.003 \\
Potassium & 10.9 & 15.3 & 7.7 & 12.5 & 14.32 & 0.040 \\
Calcium & 41.6 & 33.9 & 29.7 & 23.9 & 8.30 & $<0.001$ \\
Magnesium & 1177.5 & 578.5 & 520.5 & 333.5 & 18.20 & $<0.001$ \\
Manganese & 68.6 & 28.7 & 31.8 & 23.2 & 18.82 & 0.014 \\
Iron & 2.5 & 1.3 & 1.2 & 3.5 & 10.60 & 0.079 \\
Sulphur & 322.8 & 318.5 & 421.4 & 188.1 & 6.79 & $<0.001$ \\
Aluminium & 13.5 & 20.3 & 15.3 & 62.9 & 19.73 & 0.001 \\
\hline
\end{tabular}

cation exchange sites of the soil solid phase) concentrations of $\mathrm{Ca}, \mathrm{K}$, and $\mathrm{Mg}$ in soil were determined by extraction from $10 \mathrm{~g}$ of soil in $50 \mathrm{~mL}$ of $1 \mathrm{M}$ ammonium nitrate after shaking for $30 \mathrm{~min}$. Extracts were filtered through Whatman no. 2 filter paper [35]. Extractable Fe concentrations were determined by extraction from $10 \mathrm{~g}$ of soil with $50 \mathrm{~mL}$ of $0.05 \mathrm{M}$ EDTA disodium salt. Soil and extractant were shaken at $20^{\circ} \mathrm{C}$ for $1 \mathrm{hr}$ before being past through a Whatman no. 40 filter paper. Exchangeable and easily reduceable $\mathrm{Mn}$ were determined by extraction by $0.2 \% \mathrm{~m} / \mathrm{V}$ quinol in $1 \mathrm{M}$ ammonium acetate from $10 \mathrm{~g}$ of soil. Soil and extractant were shaken for $30 \mathrm{~min}$ and allowed to stand for $6 \mathrm{hr}$ (with frequent, periodic shaking) before being passed through a Whatman no. 40 filter paper [34]. Concentrations of Ca, Fe, $\mathrm{K}, \mathrm{Mg}$, and $\mathrm{Mn}$ in extracts were determined by inductively coupled plasma - optical emission spectroscopy (ICP-OES). Extractable $\mathrm{Al}$ concentrations in the soil were determined by extraction with Morgan's reagent ( $1.25 \mathrm{M}$ ammonium acetate acidified to $\mathrm{pH} 4.8$ with acetic acid). A suspension was formed from $10 \mathrm{~g}$ of soil and $50 \mathrm{~mL}$ of reagent, which was left to stand for $2 \mathrm{hr}$ before being filtered and made up to a final volume of $100 \mathrm{~mL}$ [36]. Extractable and water-soluble $\mathrm{S}$ was determined as sulphate extracted from $10 \mathrm{~g}$ of soil by $50 \mathrm{~mL}$ of $0.016 \mathrm{M}$ Potassium dihydrogen orthophosphate [37]. Concentrations of $\mathrm{Al}$ and $\mathrm{S}$ in extracts were determined by ICP-OES. Plant available phosphorous was determined by shaking $0.5 \mathrm{~g}$ of soil with $100 \mathrm{ml}$ of sodium bicarbonate ( $\mathrm{pH} 8.5$ ) for $30 \mathrm{~min}$ at temperature of $20^{\circ} \mathrm{C}$, before filtering the extract through a Whatman no. 2 filter paper [38]. Phosphorous concentration in extracts was subsequently determined using the molybdenum blue method [39].

2.3. Vascular Plant Community Sampling and Analysis for Objective 1. In June 2006, the percentage cover of each vascular plant species was measured as the mean \% cover from ten random $2 \mathrm{~m} \times 2 \mathrm{~m}$ quadrats per plot. Univariate statistical analyses were carried out using SPSS 15, and multivariate analyses were carried out using nonmetric multidimensional scaling (MDS) of square root transformed data using PRIMER 5 [40].
2.4. Plant Metal Uptake for Objective 2. Plant samples were washed in $0.1 \%$ detergent solution and then in two washes of distilled water to remove adhered particles. Samples were then dried at $70^{\circ} \mathrm{C}$ for $48 \mathrm{hrs}$, before being homogenised by milling in a rotary mill. Duplicate $0.25 \mathrm{~g}$ subsamples of milled plant material were digested in $70 \%$ nitric acid for $15 \mathrm{hrs}$, before being made up to a volume of $25 \mathrm{~mL}$ [41]. Extracts were then analysed for $\mathrm{Al}, \mathrm{Cu}$, and $\mathrm{Zn}$ by ICP-OES. Treatments were compared statistically by the Kruskal-Wallis test using SPSS v 15, as no single transformation successfully homogenised all variances.

2.5. Invertebrate and Soil Sampling for Objective 3. The surface active spiders and beetles were sampled by placing pitfall traps $(6 \mathrm{~cm}$ in diameter and $7 \mathrm{~cm}$ in depth) in ten random locations across each field in which sulphur had been applied at Trehill. Each pitfall was half filled with $0.1 \%$ detergent solution and was left in place for 4 days. Soil samples were taken from within $5 \mathrm{~m}$ of each pitfall and analysed as described above.

\section{Results}

3.1. Soil Chemistry. There were significant differences in soil chemistry between treatments, control mesotrophic pasture, and heaths for all factors except concentration of iron (Table 1). The sulphur treatment resulted in a $\mathrm{pH}$ significantly below that of the control grassland and similar to that of the heath target, whilst the soil stripped treatment failed to produce a significant change in $\mathrm{pH}$ from the control (Tables 1 and 2). However, the sulphur treatment also produced significantly increased levels of available phosphate compared even to the control, whilst the soil stripped treatment reduced levels of phosphate below those of even the heath soils (Tables 1 and 2). The soil stripped treatment was also more effective in reducing availability of potassium, calcium, and magnesium. Both the treatments, particularly the soil stripped treatment, increased the availability of $\mathrm{Al}$ (Tables 1 and 2). Bonferroni adjustments were not applied as all the effects highlighted above have $P$ values well below $P=0.05$. 
TABLE 2: Levels of significance for Mann - Whitney U comparisons between each treatment and both the control and target conditions (10 replicates per treatment).

\begin{tabular}{lcccc}
\hline Soil attribute & Sulphur and & Comparison & Soil stripped and \\
control & Sulphur and heath & 0.058 & $\begin{array}{c}\text { Soil stripped and } \\
\text { heath }\end{array}$ \\
\hline $\mathrm{pH}$ & $<0.001$ & 0.230 & 0.018 & 0.005 \\
Phosphate & 0.044 & 0.239 & 0.080 & 0.237 \\
Potassium & 0.469 & 0.036 & 0.001 & 0.130 \\
Calcium & 0.007 & 0.307 & 0.002 & 0.150 \\
Magnesium & 0.001 & 0.104 & 0.019 & 0.012 \\
Manganese & 0.058 & 0.031 & 0.130 & 0.130 \\
Iron & 1.000 & 0.023 & 0.762 & 0.001 \\
Sulphur & 0.034 & 0.002 & 0.002 & 0.001 \\
Aluminium & 0.427 & 0.112 & & \\
\hline
\end{tabular}

TABLE 3: Mean \% abundance per treatment of vascular plant species. Only species that occurred in $>10 \%$ of the quadrats are listed here. H= Kruskal-Wallis test statistic.

\begin{tabular}{|c|c|c|c|c|c|c|}
\hline \multirow{2}{*}{ Species } & \multicolumn{4}{|c|}{ Treatment } & \multirow{2}{*}{$\mathrm{H}$} & \multirow{2}{*}{$P$} \\
\hline & Control & $\begin{array}{l}\text { Elemental } \\
\text { sulphur }\end{array}$ & Soil stripped & Heathland & & \\
\hline Achillea millefolium & 15.0 & 0.0 & 1.3 & 0.0 & 32.8 & $<0.001$ \\
\hline Agrostis cepilleris & 7.6 & 14.3 & 8.5 & 11.2 & 3.6 & 0.310 \\
\hline Anthoxanthum odoratum & 3.8 & 2.0 & 3.2 & 0.0 & 7.7 & 0.053 \\
\hline Bromus mollis & 2.3 & 0.0 & 0.5 & 0.0 & 18.1 & $<0.001$ \\
\hline Calluna vulgaris & 0.0 & 65.0 & 5.1 & 79.5 & 34.2 & $<0.001$ \\
\hline Dectylis glomerata & 8.2 & 0.0 & 1.6 & 0.0 & 27.3 & $<0.001$ \\
\hline Elymus repens & 24.0 & 0.0 & 1.5 & 0.0 & 33.1 & $<0.001$ \\
\hline Festuca rubra & 4.3 & 0.0 & 2.3 & 0.0 & 19.9 & $<0.001$ \\
\hline Holcus lanatus & 13.7 & 2.7 & 10.2 & 2.2 & 19.3 & $<0.001$ \\
\hline Hypochoeris radicata & 2.3 & 0.0 & 2.4 & 0.3 & 19.7 & $<0.001$ \\
\hline Lolium perenne & 29.5 & 0.0 & 2.3 & 0.0 & 32.4 & $<0.001$ \\
\hline Plantago lanceolata & 5.3 & 0.2 & 5.5 & 0.0 & 29.3 & $<0.001$ \\
\hline Ranunculus repens & 3.3 & 0.0 & 2.4 & 0.0 & 18.2 & $<0.001$ \\
\hline Rumex acetocella & 0.3 & 8.5 & 7.3 & 5.2 & 18.9 & $<0.001$ \\
\hline Senecio jacobaea & 1.8 & 0.0 & 1.0 & 0.0 & 11.5 & 0.009 \\
\hline Trifolium repens & 3.4 & 0.0 & 3.0 & 0.0 & 20.0 & $<0.001$ \\
\hline
\end{tabular}

3.2. Vascular Plant Community. Growth of Calluna vulgaris was much greater in the sulphur treatment that in the soil stripped treatment (Table 3 ). The other species that established quickly and grew abundantly in the sulphur treatment were Rumex acetosella and Agrostis capillaris. The soil stripped treatment has a more diverse species composition, the most abundant grasses were Holcus lanatus and A. capillaris and common forbs were R. acetosella, Plantago lanceolata, and Hypochoeris radicata (Table 3 ). Community analysis by MDS and ANOSIM found that the sulphur treatment produced a community that was not significantly different to that of the target heath $(R=0.058, P=0.176)$, whereas the soil stripped treatment did not $(R=0.986, P=$ 0.001) (Figure 1). Both treatments produced communities significantly different from the control mesotrophic grassland community (Figure 1).

3.3. Plant Metal Uptake. Plants of R. acetosella and A. capillaris growing in soils treated with higher sulphur application levels were found to accumulate significantly higher concentrations of both $\mathrm{Al}(H=11.1, P=0.025, H=$ 13.8, and $P=0.008$ for $R$. acetosella and $A$. capillaris resp.) and $\mathrm{Zn}(H=11.6, P=0.021, H=14.5$, and $P=0.006$ for $R$. acetosella and $A$. capillaries, resp.) in their shoots (Table 4). Neither species accumulated higher concentrations of $\mathrm{Cu}$ in their shoots as a consequence of soil acidification with elemental sulphur. 
TABLE 4: Effect of application level $\left(0.900,1800,2400\right.$, and $\left.3600 \mathrm{~kg} \mathrm{ha}^{-1}\right)$ of the elemental sulphur treatment on uptake of potentially toxic metals into the shoots of two plant species.

\begin{tabular}{llccccc}
\hline \multirow{2}{*}{ Element } & \multicolumn{2}{l}{ Species } & \multicolumn{4}{c}{ Sulphur treatment } \\
& & 0 & 900 & 1800 & 2400 & 3600 \\
\hline $\mathrm{Al}$ & R. acetosella & $14.3 \pm 2.1$ & $23.5 \pm 1.5$ & $24.6 \pm 2.1$ & $44.4 \pm 9.6$ & $54.3 \pm 26.3$ \\
& A. capillaris & $5.1 \pm 1.0$ & $9.2 \pm 1.6$ & $15.5 \pm 4.2$ & $4.0 \pm 0.8$ & $3.7 \pm 0.9$ \\
$\mathrm{Cu}$ & R. acetosella & $3.1 \pm 0.6$ & $3.3 \pm 0.5$ & $3.3 \pm 0.3$ & $4.3 \pm 0.6$ & $3.4 \pm 0.4$ \\
& A. capillaris & $3.9 \pm 0.2$ & $3.2 \pm 0.1$ & $4.4 \pm 0.7$ & $3.9 \pm 0.3$ & $4.2 \pm 0.5$ \\
$\mathrm{Zn}$ & R. acetosella & $26.6 \pm 1.5$ & $46.1 \pm 3.3$ & $66.6 \pm 9.4$ & $70.8 \pm 3.1$ & $91.6 \pm 4.5$ \\
& A. capillaris & $31.1 \pm 3.5$ & $26.9 \pm 2.9$ & $38.2 \pm 2.9$ & $37.0 \pm 1.5$ & $42.0 \pm 1.4$ \\
\hline
\end{tabular}

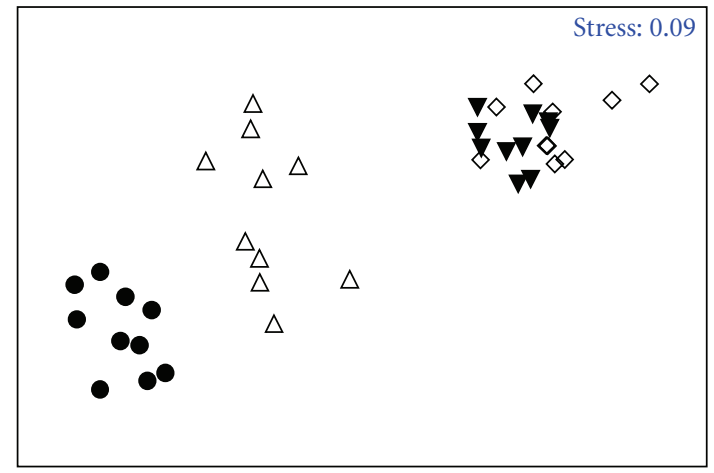

$\begin{array}{ll}\text { - Control } & \triangle \text { Soil stripped } \\ \nabla \text { Sulphur } & \diamond \text { Health }\end{array}$

FIgURE 1: MDS plot showing the differences in overall plant community composition of the ten replicates from each treatment compared to control mesotrophic grasslands and targets heaths. The plots grouped most closely with the target heath plots in the MDS are the sulphur plots. This indicates that these are the plots with plant communities that most closely resemble the target heath communities.

3.4. Beetle and Spider Abundance Effects. Beetle abundance showed no significant relationship with soil $\mathrm{pH}(r=$ $0.29, P=0.064)$, but spider abundance showed a significant positive correlation with soil $\mathrm{pH}(r=0.44, P=0.002)$. The similar relationships were found for soil available $\mathrm{Al}$, and beetle abundance showed no correlation $(r=-0.18, P=$ 0.13 ), whereas spider abundance was significantly and negatively correlated $(r=-0.36, P=0.023)$. As available Al concentrations in soil can be correlated with $\mathrm{pH}$, a partial correlation was conducted to determine if spider abundance was still correlated with the available $\mathrm{Al}$ concentration in the soil when controlling for the effect of soil $\mathrm{pH}$. This showed that a significant correlation still existed $(r=-0.358, P=0.003)$.

\section{Discussion}

This study has found large differences in the soil chemistry and resulting plant community in heathlands restored by soil stripping and by soil acidification with elemental sulphur. We have found that the elemental sulphur treatment was the most effective in reducing $\mathrm{pH}$ and the soil stripped treatment was the most effective in reducing levels of residual phosphate. The consequence of the differences in soil chemistry between treatments in this study was that the elemental sulphur treatment produced a vegetation community that closely resembled that of target heathland, whilst the soil stripping treatment produced a slow-growing, more species diverse, mesotrophic sward. The results for soil-stripping fits with the well-established importance of phosphate in controlling the competitive strength of mesotrophic grasses [42]. The results for the elemental sulphur treatment suggests a role of low $\mathrm{pH}$ in regulating mesotrophic grasses beyond its impact on nutrient availability. Possible mechanisms include direct toxicity effects of $\mathrm{H}_{+}$on plants [43] or an indirect effect of low $\mathrm{pH}$ increasing the availability thus toxicity to plants of metals such as $\mathrm{Al}$ [44-46].

Another factor that may affect the assembly of restored heathland plant and animal communities is the mobilisation of potentially toxic elements up through trophic levels. Our results have shown that both the soil stripping treatment and the soil acidification treatment can increase the exposure of plants to potentially toxic metals although the mechanisms differ. Soil stripping results in plants growing on lower soil horizons which may contain metals leached from the upper horizons. By contrast, soil acidification changes the chemical state, solubility, and, consequently, the mobility of metals in the soil. Overall, the most important parameter in determining bioavailability of potentially toxic metal in soils is $\mathrm{pH}[47,48]$. However, the effect of changing soil $\mathrm{pH}$ on the availability of trace metals differs among elements [47, 49].

We found significant increase in plant uptake of aluminium and zinc, but not copper, as a response to soil acidification during heathland restoration. The top application rate assessed $\left(3600 \mathrm{~kg} \mathrm{ha}^{-1}\right.$ ) was the minimum required to control growth of mesotrophic competitive grasses in the quite well improved soils of our study site. A decrease in soil $\mathrm{pH}$ significantly increases the bioavailability of $\mathrm{Zn}$ and, when the $\mathrm{pH}$ falls below 5, of $\mathrm{Al}[47,48,50]$. The bioavailability of $\mathrm{Cu}$ shows a much weaker relationship with $\mathrm{pH}$ and only increases slightly due to increased acidification of the soil $[47,48]$. Thus, the acidifying effect of elemental sulphur should be reflected in increased concentrations of these elements in the plant shoots, and this is exactly what was observed in $R$. acetosella and A. capillaris. By contrast, $\mathrm{Cu}$ 
concentrations in the plant shoots were not affected by the elemental sulphur treatment, reflecting the much weaker mobilisation of this element into available forms. Increased availability of metals in the soil does not necessarily result in increased concentrations in plants shoots as many plant species can effectively prevent the translocation of metals to their shoots. Moreover, some species, including R. acetosella, have been reported as being able to detoxify $\mathrm{Al}$ around its roots by secreting organic acids to bind Al in the soil [51]. Consequently, increased availability in the soil does not necessarily lead to increased metal concentration in the shoot tissues of all plants. However, our results showed that two species that frequently occur in restored heathland are able to take up $\mathrm{Al}$ and $\mathrm{Zn}$ and translocate them to their shoots and that this effect increased in proportion to decreasing levels of soil $\mathrm{pH}$. At the highest sulphur amendment rate, there was a 3-fold increases in $\mathrm{Al}$ and $\mathrm{Zn}$ concentration in the shoots of $R$. acetosella, To put this increase in context, the shoot $\mathrm{Zn}$ concentrations found in $R$. acetosella exceed the 95\% value for herbage in England, $53.6 \mathrm{mg} \mathrm{kg}^{-1}$ [52] by a factor of 1.7 .

The results of plant metal uptake demonstrate that two PTM elements were mobilised by the sulphur treatment and entered the food chain. No direct measurements of the $\mathrm{Al}$ or $\mathrm{Zn}$ concentration were made in beetles and spiders as the inter-specific variation in metal accumulation renders such measurement meaningless in samples where different species are bulked together [53]. However, correlations show that there is a significant relationship between the abundance of spiders and the available $\mathrm{Al}$ concentration in the soil. Beetle abundance showed no affect. Thus, there were greater numbers of surface active beetles than spiders in soils with higher Al levels.

The mobility and toxicity of $\mathrm{Al}$ in terrestrial ecosystems has been very poorly studied. However, [54] showed that Al can be transferred through invertebrate food chains and that invertebrate predators may accumulate greater amounts of $\mathrm{Al}$ through oral ingestion than other predators. Piercing-sucking predators such as spiders may also be more vulnerable to PTM contamination in their food than chewing predators due to their mode of feeding [55]. There are differences in the metabolism of $\mathrm{Al}$ compared to that of the more widely studied divalent metals, but they also show similarities in the storage/detoxification mechanisms utilised by invertebrates $[54,56]$. Consequently, it is entirely possible that spiders are accumulating greater quantities of $\mathrm{Al}$ than beetles, and this is, in turn, resulting in toxic effects that are altering spider abundance. However, it is also possible that the abundance of prey species of spiders was affected to a greater degree than that of beetles. In either instance, as spiders are important prey for higher trophic levels, increased availability of $\mathrm{Al}$ in the soil may affect several trophic levels, including animal species of high conservation value.

In conclusion, this study has found that heathland restoration by soil stripping and by acidification with elemental sulphur produces very different soil chemical environments and that this can result in effects on soilplant and soil-animal interactions. The low $\mathrm{pH}$, high residual nutrient environment restored in the elemental sulphur treatment plots developed a plant community that closely resembled adjacent established, seminatural dry heathland communities within five years (in the absence of grazing). Plant community development was much slower on the nutrient-poor soil stripped plots. Both soil acidification and soil stripping have the potential to increase the availability of potentially toxic metals to plants and, thus, higher trophic level species. Soil acidification mobilises many potentially toxic metals by changing their chemical state, and soil stripping can expose plant roots to deeper soils containing higher concentrations of metals. Our study has shown that the acidification treatment can increase uptake of both $\mathrm{Al}$ and $\mathrm{Zn}$ in two plant species that are likely to be abundant on restored lowland heath, Lolium perenne and Rumex acetosella. Aluminium mobilisation, at least, also appeared to have a further effect on the community by reducing the abundance of spiders, an important group of predators, and food for higher trophic levels. Further research is needed to understand the implications of this for individual species fitness and for functioning of food chains supporting higher trophic level species.

\section{Acknowledgments}

The authors thank the National Trust, particularly Angela Peters, and Countryside Council for Wales, particularly Matt Sutton for supporting this research. They also thank Kim Newman for excellent technical assistance and two anonymous referees for their very useful comments.

\section{References}

[1] K. Piessens and M. Hermy, "Does the heathland flora in north-western Belgium show an extinction debt?" Biological Conservation, vol. 132, no. 3, pp. 382-394, 2006.

[2] N. W. Moore, "The heaths of Dorset and their conservation," Journal of Ecology, vol. 50, pp. 369-391, 1962.

[3] N. R. Webb, "Changes on the heathlands of dorset, England, between 1978 and 1987," Biological Conservation, vol. 51, no. 4, pp. 273-286, 1990.

[4] R. H. Marrs, "Techniques for reducing soil fertility for nature conservation purposes: a review in relation to research at Roper's Heath, Suffolk, England," Biological Conservation, vol. 34, no. 4, pp. 307-332, 1985.

[5] R. E. N. Smith, N. R. Webb, and R. T. Clarke, "The establishment of heathland on old fields in Dorset, England," Biological Conservation, vol. 57, no. 2, pp. 221-234, 1991.

[6] R. F. Pywell, N. R. Webb, and P. D. Putwain, "Soil fertility and its implications for the restoration of heathland on farmland in southern Britain," Biological Conservation, vol. 70, no. 2, pp. 169-181, 1994.

[7] R. Aerts, A. Huiszoon, J. H. Van Oostrum, C. A. Van De Vijver, and J. H. Willems, "The potential for heathland restoration on formerly arable land at a site in Drenthe, The Netherlands," Journal of Applied Ecology, vol. 32, no. 4, pp. 827-835, 1995.

[8] B. J. Chambers, R. B. Cross, and R. J. Pakeman, "Recreating lowland heath on ex-arable land in the Breckland Environmentally Sensitive Area," Aspects of Applied Biology, vol. 44, pp. 393-400, 1996. 
[9] R. H. Marrs, C. S. R. Snow, K. M. Owen, and C. E. Evans, "Heathland and acid grassland creation on arable soils at Minsmere: identification of potential problems and a test of cropping to impoverish soils," Biological Conservation, vol. 85, no. $1-2$, pp. 69-82, 1998.

[10] S. J. Dunsford, A. J. Free, and A. J. Davy, "Acidifying peat as an aid to the reconstruction of lowland heath on arable soil: a field experiment," Journal of Applied Ecology, vol. 35, no. 5, pp. 660-672, 1998.

[11] K. M. Owen and R. H. Marrs, "Creation of heathland on former arable land at Minsmere, Suffolk, UK: the effects of soil acidification on the establishment of Calluna and ruderal species," Biological Conservation, vol. 93, no. 1, pp. 9-18, 2000.

[12] K. M. Owen and R. H. Marrs, "The use of mixtures of sulfur and bracken litter to reduce $\mathrm{pH}$ of former arable soils and control ruderal species," Restoration Ecology, vol. 9, no. 4, pp. 397-409, 2001.

[13] C. S. Lawson, M. A. Ford, J. Mitchley, and J. M. Warren, "The establishment of heathland vegetation on ex-arable land: the response of Calluna vulgaris to soil acidification," Biological Conservation, vol. 116, no. 3, pp. 409-416, 2004.

[14] M. Tibbett and A. Diaz, "Are sulfurous soil amendments (S0, $\mathrm{Fe}(\mathrm{II}) \mathrm{SO} 4, \mathrm{Fe}(\mathrm{III}) \mathrm{SO} 4)$ an effective tool in the restoration of heathland and acidic grassland after four decades of rock phosphate fertilization?" Restoration Ecology, vol. 13, no. 1, pp. 83-91, 2005.

[15] M. Allison and M. Ausden, "Successful use of topsoil removal and soil amelioration to create heathland vegetation," Biological Conservation, vol. 120, no. 2, pp. 225-232, 2004.

[16] E. Dorland, L. J. L. Van Den Berg, A. J. Van De Berg, M. L. Vermeer, J. G. M. Roelofs, and R. Bobbink, "The effects of sod cutting and additional liming on potential net nitrification in heathland soils," Plant and Soil, vol. 265, no. 1-2, pp. 267-277, 2004.

[17] K. M. Owen, R. H. Marrs, C. S. R. Snow, and C. E. Evans, "Soil acidification-the use of sulphur and acidic plant materials to acidify arable soils for the recreation of heathland and acidic grassland at Minsmere, UK," Biological Conservation, vol. 87, no. 1, pp. 105-121, 1999.

[18] A. Diaz, I. Green, and M. Tibbett, "Re-creation of heathland on improved pasture using top soil removal and sulphur amendments: edaphic drivers and impacts on ericoid mycorrhizas," Biological Conservation, vol. 141, no. 6, pp. 1628-1635, 2008.

[19] K. J. Walker, P. A. Stevens, D. P. Stevens, J. O. Mountford, S. J. Manchester, and R. F. Pywell, "The restoration and re-creation of species-rich lowland grassland on land formerly managed for intensive agriculture in the UK," Biological Conservation, vol. 119, no. 1, pp. 1-18, 2004.

[20] R. E. Green and G. H. Griffiths, "Use of preferred nesting habitat of stone curlews Burhinus oedicnemus in relation to vegetation structure," Journal of Zoology, vol. 233, no. 3, pp. 457-471, 1994.

[21] R. E. Green, G. A. Tyler, and C. G. R. Bowden, "Habitat selection, ranging behaviour and diet of the stone curlew (Burhinus oedicnemus) in southern England," Journal of Zoology, vol. 250, no. 2, pp. 161-183, 2000.

[22] S. Cummins and J. O'Halloran, "An assessment of the diet of nestling Stonechats Saxicola torquata using compositional analysis," Bird Study, vol. 49, no. 2, pp. 139-145, 2002.

[23] R. H. W. Langston, S. R. Wotton, G. J. Conway et al., "Nightjar Caprimulgus europaeus and woodlark Lullula arborearecovering species in Britain?” Ibis, vol. 149 , no. 2, pp. 250 260, 2007
[24] A. Kabata-Pendias and H. Pendias, Trace Elements in Soils and Plants, CRC Press, Boca Raton, Fla, USA, 2nd edition, 2001.

[25] M. E. Sumner and T. Yamada, "Farming with acidity," Communications in Soil Science and Plant Analysis, vol. 33, no. 15-18, pp. 2467-2496, 2002.

[26] S. P. Hopkin and M. H. Martin, "Assimilation of zinc, cadmium, lead and copper by the centipede Lithobius variegatus (Chilopoda)," Journal of Applied Ecology, vol. 21, no. 2, pp. 535-546, 1984.

[27] R. Scheifler, A. Gomot-de Vaufleury, M. L. Toussaint, and P. M. Badot, "Transfer and effects of cadmium in an experimental food chain involving the snail Helix aspersa and the predatory carabid beetle Chrysocarabus splendens," Chemosphere, vol. 48, no. 6, pp. 571-579, 2002.

[28] N. M. Van Straalen, J. H. M. Schobben, and R. G. M. De Goede, "Population consequences of cadmium toxicity in soil microarthropods," Ecotoxicology and Environmental Safety, vol. 17, no. 2, pp. 190-204, 1989.

[29] S. P. Hopkin, G. N. Hardisty, and M. H. Martin, "The woodlouse Porcellio scaber as a 'biological indicator' of zinc, cadmium, lead and copper pollution," Environmental Pollution Series B, vol. 11, no. 4, pp. 271-290, 1986.

[30] R. Laskowski and S. P. Hopkin, "Accumulation of $\mathrm{Zn}, \mathrm{Cu}, \mathrm{Pb}$ and $\mathrm{Cd}$ in the garden snail (Helix aspersa): implications for predators," Environmental Pollution, vol. 91, no. 3, pp. 289297, 1996.

[31] M. B. Pedersen, E. J. M. Temminghoff, M. P. J. C. Marinussen, N. Elmegaard, and C. A. M. Van Gestel, "Copper accumulation and fitness of Folsomia candida Willem in a copper contaminated sandy soil as affected by $\mathrm{pH}$ and soil moisture," Applied Soil Ecology, vol. 6, no. 2, pp. 135-146, 1997.

[32] K. B. Gongalsky and N. M. van Straalen, "The impact of a metallurgical plant on ground beetle (Coleoptera, Carabidae) communities," in Pollution Induced Change in Soil Invertebrate Food-Webs, R. O. Butovsky and N. M. van Straalen, Eds., Vrije Iniversiteit, Amsterdam, The Netherlands, 1999.

[33] A. V. Tanasevitch, "The effect of metallurgic smelter pollution on spider communities (Arachnidia, Araneae) preliminary observations," in Pollution Induced Change in Soil Invertebrate Food-Webs, R. O. Butovsky and N. M. van Straalen, Eds., vol. 2, Vrije Iniversiteit, Amsterdam, The Netherlands, 1999.

[34] R. F. Pywell, N. R. Webb, and P. D. Putwain, "A comparison of techniques for restoring heathland on abandoned farmland," Journal of Applied Ecology, vol. 32, no. 2, pp. 400-401, 1995.

[35] MAFF (Ministry of Agriculture Fisheries \& Food), Agriculture Development and Advisory Service Reference Book 427. The Analysis of Agricultural Materials, HMSO, London, UK, 1986.

[36] E. O. McLean, "Aluminium," in Methods of Soil Analysis: Part 2 Chemical and Microbiological Properties, C. A. Black, D. D. Evans, J. L. White, L. E. Ensminger, and F. E. Clark, Eds., pp. 978-998, American Society of Agronomy, Madison, Wis, USA, 1965.

[37] J. S. Knights, F. J. Zhao, S. P. McGrath, and N. Magan, “Longterm effects of land use and fertiliser treatments on sulphur transformations in soils from the Broadbalk experiment," Soil Biology and Biochemistry, vol. 33, no. 12-13, pp. 1797-1804, 2001.

[38] S. R. Olsen, C. V. Cole, F. S. Watanbe, and L. A. Dean, Estimation of Available Phosphorous in Soil by Extraction with Sodium Bicarbonate, United States Department of Agriculture, Washington, DC, USA, 1954. 
[39] J. Murphy and J. P. Riley, "A modified single solution method for the determination of phosphate in natural waters," Analytica Chimica Acta, vol. 27, no. C, pp. 31-36, 1962.

[40] K. R. Clark and R. M. Warwick, Changes in Marine Communities: An Approach to Statistical Analysis and Interpretation, PRIMER-E, Plymouth, UK, 2nd edition, 2001.

[41] G. Merrington, L. Winder, and I. Green, "The uptake of cadmium and zinc by the bird-cherry oat aphid Rhopalosiphum padi (Homoptera:Aphididae) feeding on wheat grown on sewage sludge amended agricultural soil," Environmental Pollution, vol. 96, no. 1, pp. 111-114, 1997.

[42] J. P. Grime, "Evidence for the existence of three primary strategies in plants and its relevance to ecological and evolutionary theory," The American Naturalist, vol. 111, no. 982, pp. 11691194, 1977.

[43] T. B. Kinraide, "Toxicity factors in acidic forest soils: attempts to evaluate separately the toxic effects of excessive $\mathrm{Al}^{3+}$ and $\mathrm{H}^{+}$and insufficient $\mathrm{Ca}^{2+}$ and $\mathrm{Mg} 2+$ upon root elongation," European Journal of Soil Science, vol. 54, no. 2, pp. 323-333, 2003.

[44] J. W. Huang, D. M. Pellet, L. A. Papernik, and L. V. Kochain, "Aluminium interactions with voltage-dependent calcium transport on plasma membrane vesicles isolated from roots of aluminium-sensitive and -resistant wheat cultivars," Plant Physiology, vol. 110, no. 2, pp. 561-569, 1996.

[45] T. Mossor-Pietraszewska, "Effect of aluminium on plant growth and metabolism," Acta Biochimica Polonica, vol. 48, no. 3, pp. 673-686, 2001.

[46] G. R. Rout, S. Samantaray, and P. Das, "Aluminium toxicity in plants: a review," Agronomie, vol. 21, no. 1, pp. 3-21, 2001.

[47] D. R. Sauerbeck, "Plant, element and soil properties governing uptake and availability of heavy metals derived from sewage sludge," Water, Air, and Soil Pollution, vol. 57-58, pp. 227-237, 1991.

[48] M. Puschenreiter and O. Horak, "Influence of different soil parameters on the transfer factor soil to plant of $\mathrm{Cd}, \mathrm{Cu}$ and Zn for wheat and rye," Bodenkultur, vol. 51, no. 1, pp. 3-10, 2000.

[49] P. Planquart, G. Bonin, A. Prone, and C. Massiani, "Distribution, movement and plant availability of trace metals in soils amended with sewage sludge composts: application to low metal loadings," Science of the Total Environment, vol. 241, no. 1-3, pp. 161-179, 1999.

[50] C. D. Foy, A. M. Sadeghi, J. C. Ritchie, D. T. Krizek, J. R. Davis, and W. D. Kemper, "Aluminum toxicity and high bulk density: role in limiting shoot and root growth of selected aluminum indicator plants and eastern gamagrass in an acid soil," Journal of Plant Nutrition, vol. 22, no. 10, pp. 1551-1566, 1999.

[51] M. Schöttelndreier, M. M. Norddahl, L. Ström, and U. Falkengren-Grerup, "Organic acid exudation by wild herbs in response to elevated $\mathrm{Al}$ concentrations," Annals of Botany, vol. 87, no. 6, pp. 769-775, 2001.

[52] UK SHS, UK soil and herbage pollutant survey report No. 1, Environmental Agency, Bristol, UK, 2007.

[53] N. M. Van Straalen and J. Van Wensem, "Heavy metal content of forest litter arthropods as related to body-size and trophic level," Environmental Pollution Series A, vol. 42, no. 3, pp. 209 221, 1986.

[54] R. C. Walton, C. R. McCrohan, F. Livens, and K. N. White, "Trophic transfer of aluminium through an aquatic grazeromnivore food chain," Aquatic Toxicology, vol. 99, no. 1, pp. 93-99, 2010.
[55] F. Hendrickx, J. P. Maelfait, and F. Langenbick, "Absence of cadmium excretion and high assimilation result in cadmium biomagnification in a wolf spider," Ecotoxicology and Environmental Safety, vol. 55, no. 3, pp. 287-292, 2003.

[56] R. Elangovan, C. R. McCrohan, S. Ballance, J. J. Powell, and K. $\mathrm{N}$. White, "Localization and fate of aluminium in the digestive gland of the freshwater snail Lymnaea stagnalis," Tissue and Cell, vol. 32, no. 1, pp. 79-87, 2000. 

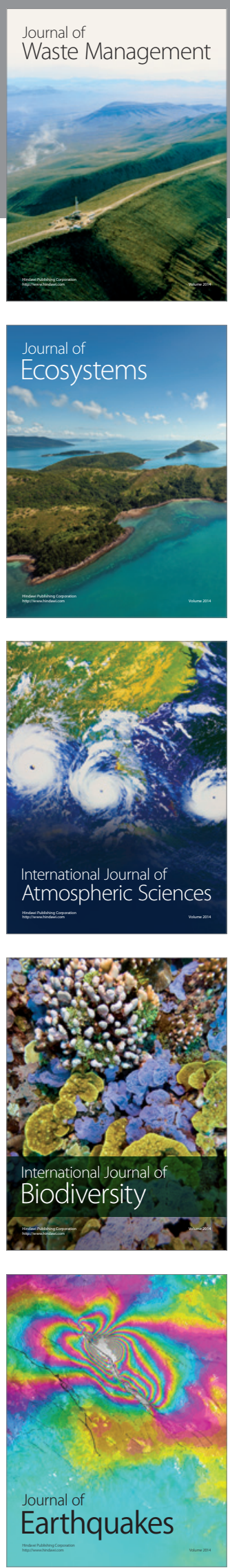
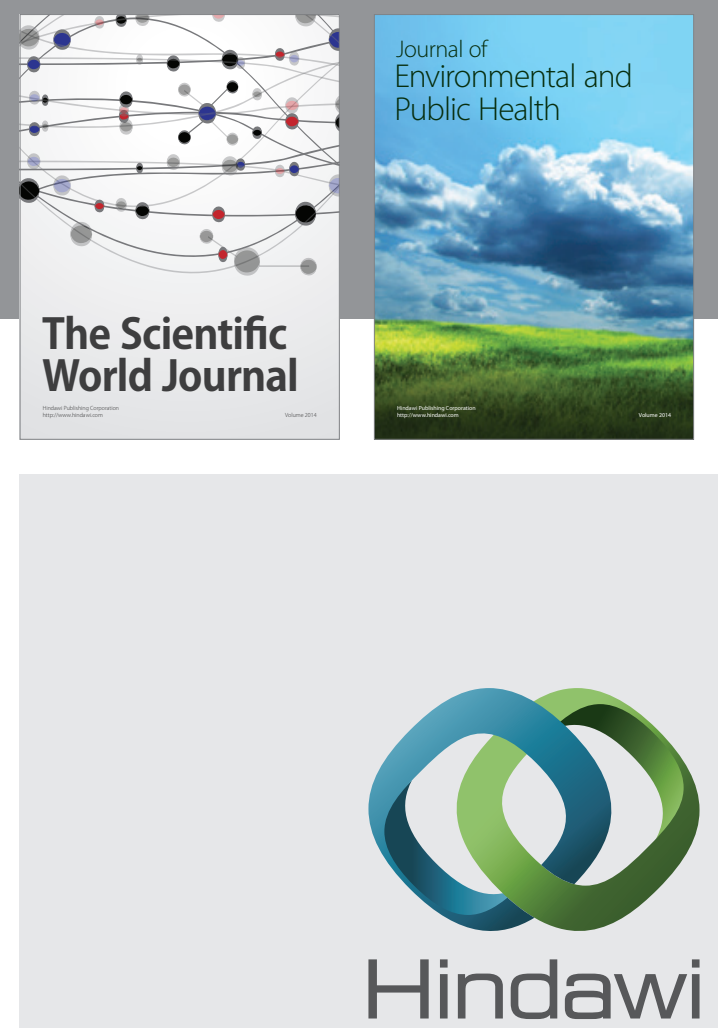

Submit your manuscripts at

http://www.hindawi.com
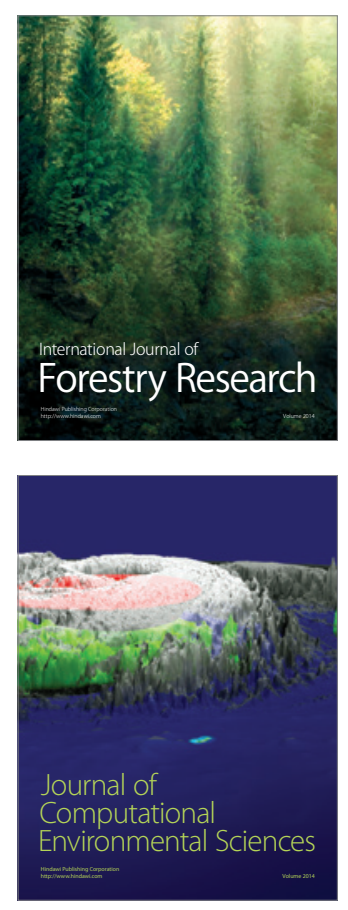
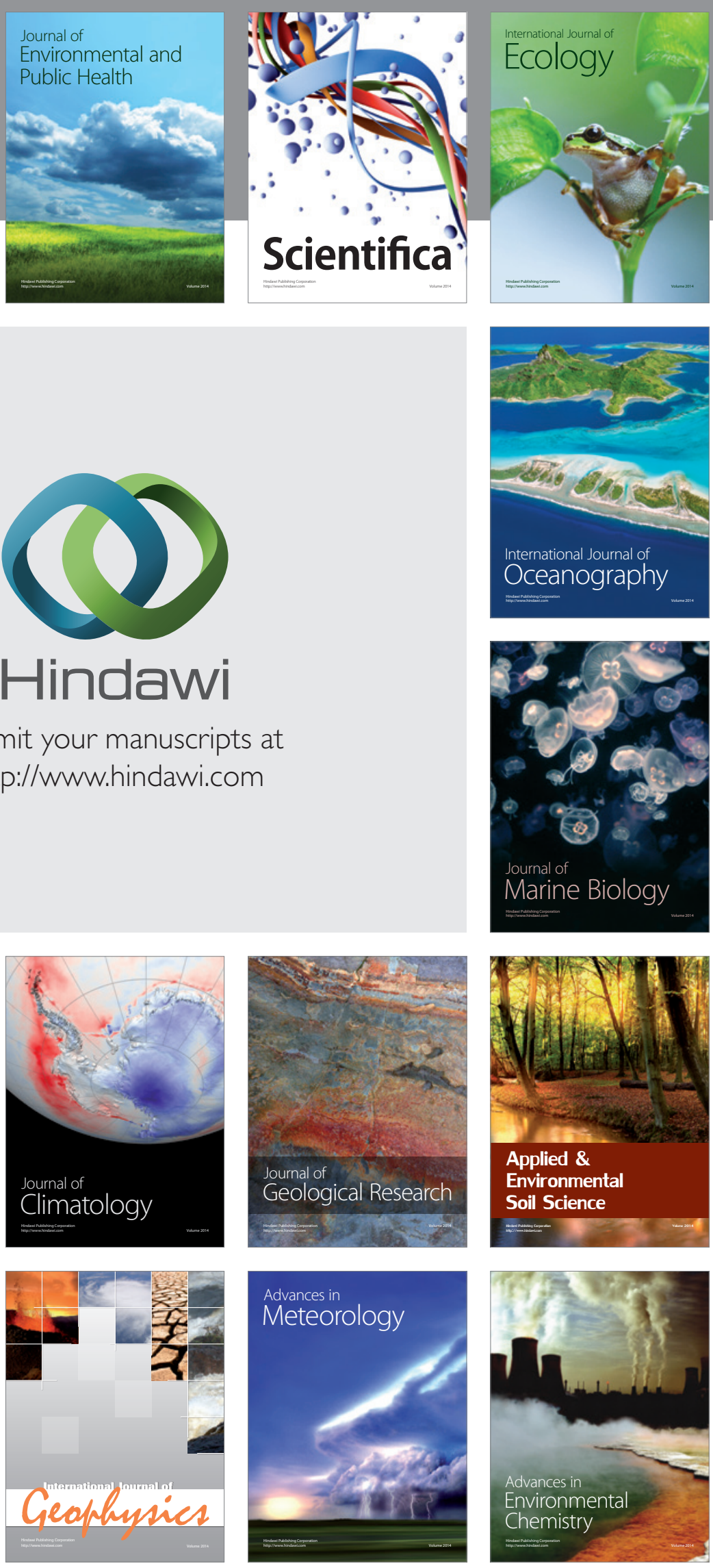